\title{
EL MÚSICO COMO INTELECTUAL. ADOLFO SALAZAR Y LA CREACIÓN DEL DISCURSO DE LA VANGUARDIA MUSICAL ESPAÑOLA (1914-1936)
}

FRANCISCO PARRALEJO MASA

\author{
Madrid, Sociedad Española de Musicología, 2019, 484 páginas \\ ISBN: 978-84-86878-86-3
}

El crítico musical Adolfo Salazar (1890-1958) fue un personaje más destacado de lo que una mirada superficial y genérica sobre la historia de la música española de la primera mitad del XX pudiera revelar. Habitualmente se le ha considerado un erudito bien relacionado con los compositores españoles más importantes de su tiempo, pero casi siempre situado en un rol de actor secundario dentro del contexto cultural que le tocó vivir. Sin embargo, la monografía aquí reseñada analiza la trascendental labor que Adolfo Salazar desarrolló como aglutinador de la vanguardia musical española a través de sus textos críticos y de las interacciones que éstos generaron con escritores y compositores de su época. Asimismo, también las polémicas que tuvo con otros intelectuales y sus abusos de poder frente a sus rivales. El indudable interés del estudio desarrollado por Francisco Parralejo le ha proporcionado el reconocimiento de la Sociedad Española de Musicología con el Premio de Musicología “Lothar Siemens 2017’ por su contribución a la investigación del patrimonio musical hispano.

Las páginas de este libro, que se lee de modo ágil gracias a su prosa fluida y a una adecuada progresión en la exposición de contenidos, centra su mirada en el período 19141936, uno de los más ricos desde el punto de vista creativo y también uno de los más influyentes de la historia de la cultura española. Asimismo, fue la etapa en la que se logró superar la situación marginal que dentro de las artes sufría la música desde el reinado de Fernando VII. En estos años, la eclosión del nacionalismo musical cimentado sobre las aportaciones de creadores y teóricos como Pedrell, Granados, Albéniz o Falla, entre otros, además del comienzo del desarrollo de las vanguardias, lograron que la actividad musical se situara en el centro de la escena cultural española del mismo modo en que desde hacía décadas se producía en otros países del entorno. Uno de los indicadores del crecimiento de la importancia de este campo creativo puede encontrarse, como bien se analiza en las páginas de este libro, en el pensamiento de la generación de 1914 que integró, aunque no plenamente, la música en los debates intelectuales más destacados de la España de aquel período. 
Francisco Parralejo explica de modo elocuente cómo en este proceso de integración generado por múltiples causas tuvo un papel fundamental Adolfo Salazar, lo que justifica que este personaje sea el núcleo de un estudio que, sin embargo, va más allá de la reconstrucción concreta de sus actividades al situarlo como una pieza clave dentro del complejo entramado intelectual del momento. Una de las causas que hicieron de Salazar un actor influyente fue la amplificación que su discurso tuvo en el periódico El Sol y, quizás en menor media, en La Vo\% Sus escritos tuvieron un nutrido y fiel conjunto de lectores que, a su vez, generaron comentarios sobre ellos que aumentaban el alcance inicial. Asimismo, la erudición del personaje y su más que notable inquietud intelectual hizo que sus páginas fueran ricas en referencias a la bibliografía internacional, no sólo la que se ceñía al ámbito musical, sino también a otros campos del saber. Adolfo Salazar, como revela esta monografía, fue clave para la construcción de un nuevo modelo de vanguardia, más actualizado e integrado en el marco europeo, en el que Manuel de Falla tendría una contribución decisiva. El más alto grado de influencia de Salazar se produciría en 1931, una vez proclamada la II República, cuando fue elegido como responsable del diseño del nuevo organigrama institucional de la música del régimen republicano, que se mostraba así interesado en un campo cultural marginal tan sólo tres décadas atrás.

Tras un esclarecedor prólogo de José Máximo Leza y un preámbulo en el que autor realiza una acertada reflexión acerca de la denominada "Edad de Plata", el capítulo primero se adentra en una aguda reflexión sobre el papel del músico como intelectual dentro de la generación de 1914, estableciéndose no sólo las fronteras entre la vieja y nueva política, sino la contribución de la crítica musical desarrollada en El Sol y La Voz y su importancia en la configuración del discurso musical. Todo ello dentro del marco de implantación institucional del pensamiento nacionalista español, poco desarrollado y disperso hasta que la derrota frente a los Estados Unidos y la pérdida de las últimas colonias de ultramar en 1898 estimularon la reconstrucción de la identidad nacional bajo presupuestos intelectuales diversos. Asimismo, la relación con intelectuales de otros campos, como Ortega y Gasset, y las consecuencias del cambio generacional en todo el proceso de desarrollo de las vanguardias. Es interesante comprobar la consolidación del wagnerismo y su contribución a la consolidación del canon alemán que tanta importancia tendría en la evolución creativa, interpretativa y docente. El análisis, además, se apoya en un útil y abundante aparato gráfico.

En el segundo capítulo se analiza el cómo se va construyendo el nuevo discurso musical, que rompe con el academicismo anterior y el Romanticismo, y que crea el previsible y recurrente debate entre la necesidad de ruptura con el pasado y la pertinencia de continuidad. 
Francisco Parralejo analiza los argumentos por los que Salazar pretendía llenar de contenido el marco teórico establecido por Ortega y Gasset con el fin renovar las bases musicales españolas en tres ámbitos: el sistema académico, los paradigmas estéticos y el orden social. Esta labor dio sus frutos en la consagración de un nuevo modelo estético que, paralelamente, generó la agrupación de un importante conjunto de compositores, teóricos y críticos que se autodefinieron como "nuevos" y que pretendían ser reconocidos como la autoridad referencial en el futuro ordenamiento musical.

El tercer capítulo está dedicado al estudio de los cimientos teóricos de la música de vanguardia y su relación con otras corrientes. Esto lleva al autor a reconstruir los interesantes lazos de conexión establecidos entre el hispanismo francés, el nacionalismo musical español y la corriente neoclásica, lo que permite la apertura definitiva al exterior de la actividad intelectual del país, superándose las recomendaciones casticistas de Unamuno que abogaban por concentrar el interés en los rasgos propios y rechazaba la mirada al exterior. Asimismo, estudia el papel jugado por Adolfo Salazar en este proceso a través de su labor como crítico, aunque lastrado por una obsesión predicadora que terminaría siendo una de sus principales deficiencias como analista y un anticipo de la arbitrariedad y el nepotismo que el personaje mostraría cuando ocupó cargo político en la II República.

Muy acertadamente, el autor tiene presentes las teorías de Hobsbawm y Ranger acerca de la invención de tradiciones que todos los procesos de construcción nacional tienen con el fin de crear, legitimar y consolidar una determinada identidad colectiva que es, en definitiva, una de las bases fundamentales del edificio nacional. En ello juega un papel esencial la creación intelectual que, si logra ser asumida por una amplia mayoría del colectivo al que va destinada, lleva al proyecto nacionalista al éxito. En particular, en lo que se refiere a la contribución de la música, su capacidad simbólica y su ausencia de barreras idiomáticas la hacen especialmente útil para el ejercicio identitario ante propios y frente a extraños.

Hasta aquí el libro se centra principalmente en la figura de Salazar, pero acertadamente el autor lo pone en contraste con otros escritores de su época en el cuatro y último capítulo. Para ello organiza dos grupos de autores: los que escriben en medios más conservadores que los que dieron soporte editorial a Salazar, fundamentalmente de $A B C$ e Informaciones, con los críticos Ángel María Castell y Víctor Ruiz Albéniz; y los que trabajan desde una posición más progresista, principalmente desde El Liberal y El Socialista, concretado en los casos de José Subirá y Julio Gómez, con los que mantuvo unas significativas e interesantes polémicas. Particularmente importante es el caso de Subirá, ya que fue el opositor más fuerte que Salazar encontró en su gestión al frente de la Junta Nacional durante la II República. 
Éste reaccionó promoviendo su persecución política desde la privilegiada posición que le otorgaba estar dentro de las instituciones estatales. Francisco Parralejo apunta acertadamente que Subirá fue la única persona que podría haber establecido una teoría crítica alternativa a la propuesta por Salazar y que, debido a su marginación, éste logró erigirse en el modelo historiográfico hegemónico de la música española hasta bastante tiempo después de su fallecimiento.

El corpus del trabajo se sostiene sobre una rigurosa crítica textual y un sólido y abundante soporte de fuentes primarias, fundamentalmente hemerográficas, y bibliográficas. La recomendable lectura de sus páginas dimensiona con claridad la importancia del período estudiado y justifica sobradamente el por qué fue conocido como la "Edad de Plata" de la cultura española.

En definitiva, este destacable libro ofrece una novedosa perspectiva de la historia de la música en España, y, a juicio del que escribe, aporta nuevas luces al complejo y multifacético conocimiento del siglo XX. Asimismo, esta publicación es una prueba de los avances de la música durante la II República, con sus luces y sus sombras. Aunque las propuestas organizativas de Adolfo Salazar desarrolladas durante aquel período no pudieron llegar a materializarse, su nombramiento como responsable institucional de asuntos musicales demostró, no sólo la importancia del personaje, sino que, definitivamente, se había producido un cambio que habría resultado inimaginable treinta años antes: una transformación que logró que el músico trascendiera su condición periférica y se situara en el centro de la escena intelectual. Asimismo, también quedó demostrado el poder que llegó a acumular, como queda de manifiesto en su campaña de aislamiento de aquellos que ponían en evidencia las debilidades conceptuales de sus teorías, como sucedió con Julio Gómez y José Subirá.

Joaquín Piñeiro Blanca

Universidad de Cádiz 